\title{
Effect of Combined Application of Foliar Sprays of Orthosilicic Acid (OSA) with Basal NPK Fertilizer on Growth and Yield of Rice (Oryza sativa L.)
}

Saidi Rumanzi Mbaraka ( $\nabla$ saidirumanzi@gmail.com )

University of Rwanda College of Agriculture Animal Sciences and Veterinary Medicine https://orcid.org/0000-0001-6642-0161

Jean Claude Abayisenga

University of Rwanda College of Agriculture Animal Sciences and Veterinary Medicine

Christian Nkurunziza

Rwanda Agriculture and Animal Resources Board

Francois Xavier Rucamumihigo

University of Rwanda College of Agriculture Animal Sciences and Veterinary Medicine

Sylvestre Habimana

University of Rwanda College of Agriculture Animal Sciences and Veterinary Medicine

\section{Loc Van Nguyen}

Vietnam National University of Agriculture

Ivan Gasangwa

Kyushu University: Kyushu Daigaku

Jain Neeru

Privi Life Sciences (Rwanda) Ltd

\section{Eularie Mutamuliza}

University of Rwanda College of Agriculture Animal Sciences and Veterinary Medicine

Fabrice Musana Rwalinda

University of Rwanda College of Agriculture, Animal Sciences and Veterinary Medicine

Pascal Rushemuka

Rwanda Agriculture and Animal Sciences

\section{Research Article}

Keywords: Orthosilicic acid, Recommended dose of fertilizer, Foliar spray, Yield, Rice

Posted Date: May 10th, 2021

DOl: https://doi.org/10.21203/rs.3.rs-457545/v1

License: (a) (1) This work is licensed under a Creative Commons Attribution 4.0 International License. Read Full License 
Version of Record: A version of this preprint was published at Silicon on August 10th, 2021. See the published version at https://doi.org/10.1007/s12633-021-01308-9. 


\section{Abstract \\ Purpose}

Benefits of silicon to plant growth and yield in higher plants has been explored recently. This study was conducted to assess the effects combined application of foliar application of Orthosilicic Acid (OSA) with basal NPK fertilizer on growth and yield of rice.

\section{Methods}

The study was conducted in Ntende site at Rwagitima marshland, Gatsibo district in the Eastern province of Rwanda. The field experiment was laid in randomized complete block design with three replications across in two cropping seasons in 2019/2020. Two recommended doses of fertilizer (RDF); $100 \%$ RDF (200 kgha ${ }^{-1}$ NPK and $100 \mathrm{kgha}^{-1}$ Urea) and 75\% RDF (150 kgha-1 NPK and $75 \mathrm{kgha}^{-1}$ Urea) were used in combination with different doses of silixol orthosilicic acid (OSA). The Si fertilizers were applied in liquid form at panicle initiation and grain filling stages.

\section{Results}

Combined application of OSA with RDF produced better growth attributes (plant height, number of tillers, root length, flag leaf length and width) compared with using RDF only. Similarly, OSA application showed higher yield components, number of panicles, panicle weight, grain weight per panicle and 1000-grain weight. Highest yield of $5.81 \mathrm{t} / \mathrm{ha}$ which equates to $24 \%$ increase was obtained when $100 \% \mathrm{RDF}+4 \mathrm{ml} / \mathrm{I}$ OSA was applied.

\section{Conclusion}

Rice fertilization with Si helps to stimulate plant growth, yield attributes and yield. Therefore, potential of Si could further be explored among rice farmers in Rwanda.

\section{Introduction}

Silicon (Si) occupies about $27.8 \%-32 \%$ of the earth's crust, and this makes Si second most abundant element in the earth's crust after oxygen $(46 \%)[1,2]$. Si is present in the earth's crust as quartz $\left(\mathrm{SiO}_{2}\right)$, which is the most common mineral found in sands [3). However, $\mathrm{SiO}_{2}$ in its form cannot be utilized by plants [4]. Plants absorb $\mathrm{Si}$ from soil solution in form of Monosilicic acid $\left(\mathrm{H}_{4} \mathrm{SiO}_{4}\right)$, which is often synonymously named as orthosilicic acid (OSA) [5]. Silixol is commonly applied stable formulation of OSA, and has been used as a Si fertilizer to enhance better plant growth and yield in several crops $[6,7)$.

The Si accumulation in plants varies greatly depending on the species and Si content in the soil and normally ranges from $0.1-10 \%$ on dry weight basis $[8,9,10]$. Graminaceous plants such as barley (Hordeum vulgare), 
sorghum (Sorghum bicolor) and wheat (Triticum aestivum) and rice (Oryza sativa) have been categorized as high Si accumulators [11]. Fore instance, rice was found to accumulate $4.17 \%$ of $\mathrm{Si}$ in its shoot [12].

$\mathrm{Si}$ is the only non-essential nutrient that is included in the guidelines for rice fertilization [13]. Si fertilization has been reported beneficial to rice plant growth and yield [14]. Si increases photosynthetic rate [15], plant leaf area [16] and chlorophyll content [17]. Si also has a major role in increasing rice yield attributing characters $[18,19]$. Additionally, Si has been reported to play a vital role in limiting the adverse effects of abiotic and biotic stresses in rice. Si application can enhance rice resistance to brown spot [20] and blast [21]. Si can enhance tolerance of rice to radiation [22], salinity [23] and drought [24]. Application of Si was also reported to reduce accumulation of toxic arsenic [23] and cadmium [24] in rice grains.

Despite these numerous benefits of Si to the rice crop, many farmers in Rwanda have not explored the potential $\mathrm{Si}$ as an exogenous fertilizer for their sustainable rice production. This study was conducted to assess the effects of combined application of different doses of foliar sprays of Orthosilicic acid (OSA) with basal NPK fertilizer of the growth and yields of rice.

\section{Materials And Methods}

\subsection{Experimental Site}

This study was conducted in Gatsibo district and the field experiments were carried in Rwagitima marshland ( $1^{\circ} 52^{\prime} 50^{\prime \prime}$ S latitude, 30 50'20" East longitude) in the Eastern Agro-ecological zone, Eastern Province, Rwanda. The experiments were conducted in 2019-2020 in two seasons (February to June) and (September to January) (Table 1). The basic properties of the site were; clay-loam type, pH 6.20, EC $361 \mu \mathrm{S} / \mathrm{Cm}$, CEC 23.4 meq $/ 100 \mathrm{~g}$, organic carbon $3.04 \%$, total nitrogen $0.17 \%$, available nitrogen $1.9 \mathrm{ppm}$, exchangeable calcium $4.92 \mathrm{meq} / 100 \mathrm{~g}$, exchangeable potassium $0.31 \mathrm{meq} / 100 \mathrm{~g}$ and exchangeable magnesium $2.07 \mathrm{meq} / 100 \mathrm{~g}$. 
Table 1

Mean monthly temperatures and precipitation data for the two seasons in 2019 and 2020

\begin{tabular}{|lllll|}
\hline Year & Month & Maximum Temp $\left({ }^{\circ} \mathrm{C}\right)$ & Minimum Temp $\left({ }^{\circ} \mathrm{C}\right)$ & Precipitation $(\mathrm{mm})$ \\
\hline 2019 & February & 28.9 & 15.6 & 65.6 \\
\hline & March & 28.2 & 12.1 & 80.2 \\
\hline & April & 26.8 & 17.0 & 113.7 \\
\hline May & 25.8 & 17.5 & 72.5 \\
\hline & June & 26.6 & 17.2 & 73.1 \\
\hline & September & 28.1 & 16.8 & 85.2 \\
\hline & October & 25.5 & 16.6 & 175.5 \\
\hline & November & 25.8 & 16.7 & 132.1 \\
\hline 2020 & January & 26.9 & 16.9 & 125.6 \\
\hline Source: Rwanda Meteorology Agency & 17.1 & 121.1 \\
\hline
\end{tabular}

\subsection{Treatment Structure and Experimental Design}

The experiments were laid in a randomized complete block design with three replications and eight treatments. Silixol (a stabilized form of orthosilicic acid (OSA) with $0.6 \%$ concentration) was applied as a source of Si element. The treatments were: $T_{1}$ (recommended fertilizer dose (RDF); $200 \mathrm{~kg} \mathrm{ha}^{-1} \mathrm{NPK}$ (17.17.17) and $100 \mathrm{~kg} \mathrm{ha}^{-1}$ Urea), $\mathrm{T}_{2}$ (75\% of RDF; $150 \mathrm{~kg} \mathrm{ha}^{-1} \mathrm{NPK}$ and $\left.75 \mathrm{~kg} \mathrm{ha}^{-1} \mathrm{Urea}\right), \mathrm{T}_{3}\left(\mathrm{~T}_{1}+2 \mathrm{ml}\right.$ of silixol per litre of water), $T_{4}\left(T_{1}+3 \mathrm{ml}\right.$ of silixol per litre of water), $T_{5}\left(T_{1}+4 \mathrm{l} \mathrm{ml}\right.$ of silixol per litre of water), $T_{6}$ $\left(T_{2}+2 \mathrm{ml}\right.$ of silixol per litre of water), $T_{7}\left(T_{2}+3 \mathrm{ml}\right.$ of silixol per litre of water) and $\mathrm{T}_{8}\left(\mathrm{~T}_{2}+4 \mathrm{ml}\right.$ of silixol per litre of water) (Table 2). NPK (17-17-17) was applied during planting while urea was used for top-dressing at both mid-tillering and at panicle initiation stages. The silixol liquid was foliarly applied both at panicle initiation and grain filling stages using a handheld sprayer. The regular recommended crop management practices were followed for all treatments until harvesting. 
Table 2

Fertilizer application at different stages of plant growth

\begin{tabular}{|llllll|}
\hline & Planting & Mid tillering & Panicle initiation & Grain filling \\
\hline Treatments & NPK $\left(\mathrm{kg} \mathrm{ha}^{-1}\right)$ & Urea $\left(\mathrm{kg} \mathrm{ha}^{-1}\right.$ & Urea $\left(\mathrm{kg} \mathrm{ha}^{-1}\right.$ & Silixol $\left(\mathrm{ml} \mathrm{I}^{-1}\right)$ & Silixol $\left(\mathrm{ml} \mathrm{I}^{-1}\right)$ \\
\hline T1 & 200 & 50.0 & 50.0 & 0 & 0 \\
\hline T2 & 150 & 37.5 & 37.5 & 0 & 0 \\
\hline T3 & 200 & 50.0 & 50.0 & 2 & 2 \\
\hline T4 & 200 & 50.0 & 50.0 & 3 & 3 \\
\hline T5 & 200 & 50.0 & 50.0 & 4 & 4 \\
\hline T6 & 150 & 37.5 & 37.5 & 2 & 2 \\
\hline T7 & 150 & 37.5 & 37.5 & 3 & 3 \\
\hline T8 & 150 & 37.5 & 37.5 & 4 & 4 \\
\hline
\end{tabular}

\subsection{Growth, Yield and Yield components}

Plant height, number of tillers per hill and root length data were collected from ten randomly selected hills. The plant height was measured from the bottom to the top most leaf, numbers of tillers per hill were counted and root length was recorded from the base of the plant to the tip of the longest root. For yield attributes, number of panicles, panicle weight, grain weight per panicle and 1000 grains weight were measured. Grain yield was recorded at harvesting.

\subsection{Statistical Analysis}

The data were analyzed using analysis of variance (ANOVA), GenStat data analysis software. Treatment effects were significant at $p \leq 0.05$ and means were separated by Fisher's protected least significant difference (LSD).

\section{Results And Discussion}

\subsection{Growth Parameters}

Foliar application of Si fertilizer in combined with different doses of standard fertilizer practice significantly affected growth parameters (Table 2). Plant height significantly increased when Si was applied. An increase in number of tillers was also observed among treatments that received Si fertilizer. The effect of Si was highly significant $(P<0.01)$ for root length (Table 2), flag leaf width and length (Fig. 1). Across all treatments, RDF + $4 \mathrm{ml} / \mathrm{I}$ Silixol OSA liquid $\left(T_{5}\right)$ resulted into better rice growth attributes compared with controls (RDF only). These results are in agreement with the findings of Pati et al. [27], who reported an increase in growth attributes of rice as a result of $\mathrm{Si}$ addition. Plant height of wheat was also increased by application of liquid silicon [28]. Moreover plant height is an important indicator of rice grain yield potential [29]. Increase in plant height might be attributed to Si accumulation in the cell wall that leads to plant erectness [30]. Increased 
number of tillers as a result of Si application was previously reported by Hosseini, et al. [31] and [32]. The increased number tiller might be due enhanced tillering capacity has been associated with a high supply of silicon [33]. Our findings are similar to Hattori et al. [34] who reported the positive effects of Si in increasing root length. Increase in flag area due to Si application was also reported by Dorairaj et al. [35].

Table 3

Effects of foliar application of combined doses of standard fertilizer practice and Silixol on growth parameters of rice

\begin{tabular}{|c|c|c|c|c|c|c|}
\hline \multirow[t]{2}{*}{ Treatment } & \multicolumn{2}{|c|}{$\begin{array}{l}\text { Recommended dose of fertilizer } \\
\text { (RDF) (kg/ha) }\end{array}$} & \multirow{2}{*}{$\begin{array}{l}\text { Silixol } \\
\text { foliar } \\
\left(\mathrm{ml} \mathrm{I}^{-1}\right)\end{array}$} & \multirow[t]{2}{*}{$\begin{array}{l}\text { Plant height } \\
\text { (cm) }\end{array}$} & \multirow[t]{2}{*}{$\begin{array}{l}\text { Number of } \\
\text { tillers }\end{array}$} & \multirow[t]{2}{*}{$\begin{array}{l}\text { Root length } \\
\text { (cm) }\end{array}$} \\
\hline & NPK & Urea & & & & \\
\hline T1 & 200 & 100 & 0 & $92.63^{a}$ & $261^{a b c}$ & $11.5^{\mathrm{abc}}$ \\
\hline T2 & 150 & 75 & 0 & $91.25^{\mathrm{a}}$ & $216^{a}$ & $10.02^{\mathrm{a}}$ \\
\hline T3 & 200 & 100 & 2 & $94.33^{a b c}$ & $281^{a b c}$ & $12.57^{b c}$ \\
\hline T4 & 200 & 100 & 3 & $97.65^{b c}$ & $295^{b c}$ & $13.17^{\mathrm{cd}}$ \\
\hline T5 & 200 & 100 & 4 & $99.02^{c}$ & $331^{\mathrm{c}}$ & $14.97^{d}$ \\
\hline T6 & 150 & 75 & 2 & $93.53^{\mathrm{ab}}$ & $252^{\mathrm{ab}}$ & $10.67^{a b c}$ \\
\hline T7 & 150 & 75 & 3 & $94.48^{a b c}$ & $273^{a b c}$ & $11.83^{b c}$ \\
\hline T8 & 150 & 75 & 4 & $95.78^{a b c}$ & $288^{a b c}$ & $12.75^{\mathrm{bcd}}$ \\
\hline$P$ Value & & & & $<.001^{\star \star}$ & $0.003^{*}$ & $<.001^{\star \star}$ \\
\hline$S E D$ & & & & 1.276 & 20.26 & 0.602 \\
\hline $\operatorname{LSD}_{0.05}$ & & & & 2.736 & 43.45 & 1.291 \\
\hline
\end{tabular}

\subsection{Yield Attributes and Yield of Rice}

Several yield attributes such as number of panicles, panicle weight, grain weight per panicle and 1000-grain weight were significantly affected by application Si fertilizer (Table 4). Number of panicles increased by about $21 \%$ under RDF $(100 \%)+4 \mathrm{ml} / \mathrm{l}$ of silixol treatment compared with control. This treatment also produced highest panicle length of $20.28 \mathrm{~cm}$ compared to control $(18.88 \mathrm{~cm})$, although it was not significant. Similarly, about $24 \%$ increase in panicle weight was observed with RDF $(100 \%)+4 \mathrm{ml} / \mathrm{l}$ silixol compared with only RDF $(100 \%)$. Grain weight per panicle and 1000 -grain weight were increased by about $21 \%$ and $10 \%$, respectively when RDF $(100 \%)+4 \mathrm{ml} / \mathrm{l}$ OSA was applied. Grain yield was not statistically significant with supplemental $\mathrm{Si}$ fertilizer application. Generally, Silixol OSA liquid applied in addition to RDF resulted in increased yield attributes and yield compared to the only RDF application (Table 4). Similar results depicting positive effects of Si application on yield and yield components were previously reported in rice [18,36]. The increase in yield 
attributes might be a result of $\mathrm{Si}$ improving plant growth, nutrient uptake and tolerance to abiotic and biotic stresses [37,38]. Though not statistically significant, the subsequent rice yields were increased in most of the treatments that received $\mathrm{Si}$, and were far greater than the average yield ( $4.0 \mathrm{t} / \mathrm{ha}$ ) of paddy rice in Rwanda in 2019 [39].

Table 4

Effects of combination of recommended fertilizer doses with foliar application of Silixol liquid on yield and yield attributes of rice.

\begin{tabular}{|c|c|c|c|c|c|c|c|c|c|}
\hline \multirow[t]{2}{*}{ Treatment } & \multicolumn{2}{|c|}{$\begin{array}{l}\text { Recommended } \\
\text { dose of } \\
\text { fertilizer } \\
\text { (RDF) kg/ha }\end{array}$} & \multirow[t]{2}{*}{$\begin{array}{l}\text { Silixol } \\
\text { foliar } \\
\text { (ml/l) }\end{array}$} & \multirow[t]{2}{*}{$\begin{array}{l}\text { Number } \\
\text { of } \\
\text { panicles }\end{array}$} & \multirow[t]{2}{*}{$\begin{array}{l}\text { Panicle } \\
\text { length } \\
\text { (cm) }\end{array}$} & \multirow[t]{2}{*}{$\begin{array}{l}\text { Panicle } \\
\text { weight } \\
\text { (g) }\end{array}$} & \multirow[t]{2}{*}{$\begin{array}{l}\text { Grain } \\
\text { weight } \\
\text { per } \\
\text { panicles } \\
\text { (g) }\end{array}$} & \multirow[t]{2}{*}{$\begin{array}{l}1000- \\
\text { grain } \\
\text { weight } \\
\text { (g) }\end{array}$} & \multirow[t]{2}{*}{$\begin{array}{l}\text { Yield } \\
\text { (t/ha) }\end{array}$} \\
\hline & NPK & Urea & & & & & & & \\
\hline T1 & 200 & 100 & 0 & $230^{a b c}$ & $18.88^{a}$ & $4.64^{\mathrm{ab}}$ & $4.30^{\mathrm{ab}}$ & $27.31^{a b c}$ & $4.69^{a}$ \\
\hline T2 & 150 & 75 & 0 & $204^{a}$ & $17.88^{a}$ & $4.27^{\mathrm{a}}$ & $4.06^{\mathrm{a}}$ & $24.52^{\mathrm{a}}$ & $4.35^{\mathrm{a}}$ \\
\hline T3 & 200 & 100 & 2 & $245^{a b c}$ & $19.48^{a}$ & $5.06^{\mathrm{abc}}$ & $4.76^{\mathrm{ab}}$ & $27.49^{a b c}$ & $5.08^{a}$ \\
\hline T4 & 200 & 100 & 3 & $277^{b c}$ & $19.75^{a}$ & $5.27^{b c}$ & $5.00^{\mathrm{ab}}$ & $28.65^{b c}$ & $5.69^{a}$ \\
\hline T5 & 200 & 100 & 4 & $279^{c}$ & $20.28^{a}$ & $5.74^{c}$ & $5.20^{\mathrm{b}}$ & $30.11^{c}$ & $5.81^{\mathrm{a}}$ \\
\hline T6 & 150 & 75 & 2 & $221^{\mathrm{ab}}$ & $18.02^{\mathrm{a}}$ & $4.62^{\mathrm{ab}}$ & $4.26^{\mathrm{ab}}$ & $25.53^{a b}$ & $4.53^{\mathrm{a}}$ \\
\hline T7 & 150 & 75 & 3 & $241^{a b c}$ & $19.38^{a}$ & $4.97^{\mathrm{abc}}$ & $4.54^{\mathrm{ab}}$ & $27.21^{\mathrm{abc}}$ & $4.62^{\mathrm{a}}$ \\
\hline T8 & 150 & 75 & 4 & $260^{a b c}$ & $19.69^{a}$ & $5.21^{\mathrm{abc}}$ & $4.80^{\mathrm{ab}}$ & $27.94^{\mathrm{bc}}$ & $5.25^{\mathrm{a}}$ \\
\hline$P$ Value & & & & $0.001^{\star *}$ & $\begin{array}{l}0.328 \\
\text { NS }\end{array}$ & $0.002^{\star \star}$ & $0.007^{\star \star}$ & $0.001^{\star \star}$ & $\begin{array}{l}0.195 \\
\text { NS }\end{array}$ \\
\hline$S E D$ & & & & 14.45 & 1.051 & 0.2568 & 0.2597 & 0.958 & 597.2 \\
\hline $\operatorname{LSD}_{0.05}$ & & & & 30.99 & 2.253 & 0.5508 & 0.557 & 2.055 & 1280.8 \\
\hline
\end{tabular}

\section{Conclusion}

Results of this study indicate that foliar application of Si in combination with RDF resulted in positive effects agronomic and yield-related attributes of rice. Furthermore, application of $4 \mathrm{ml} / \mathrm{l}$ of OSA with RDF would improve rice growth and yield in the rice producing regions of Rwanda. Thus, Si-fertilizers have a great potential and are worth exploring for commercial rice production.

\section{Declarations}

\section{Ethics approval and consent to participate (Not applicable)}




\section{Consent for publication (Not applicable)}

\section{Availability of data and materials}

The data that support our findings within this paper are available from the corresponding author upon reasonable request.

\section{Competing interests}

The authors declare that they have no conflict of interest with respect to research, authorship, and/or publication of this article.

\section{Funding Information}

This study was funded partially by Privi life Science (Rwanda) Limited and Swedish International Development Cooperation Agency (SIDA) through its cooperation with University of Rwanda.

\section{Author contributions}

Saidi Rumanzi Mbaraka: Jean Claude Abayisenga: and Christian Nkurunziza: Conceptualization and Experimental design (lead); Methodology (equal); Investigation (equal); and Writing original draft preparation (equal); Writing-review \& editing (equal). Francois Xavier Rucamumihigo:Sylvestre Habimana: and Loc Van Nguyen: Data curation (equal); Formal analysis (equal); Development of Figures and Tables (equal). Ivan Gasangwa: Jain Neeru: Eularie Mutamuliza: Fabrice Musana Rwalinda: Methodology (supporting); Visualization (supporting); Writing-review \& editing (equal); Funding acquisition (supporting). Pascal Rushemuka: Project administration (lead); Funding acquisition (lead); Writing-review \& editing (equal). All authors read, discussed the results, commented on the manuscript and agreed to the published version of the manuscript.

\section{Acknowledgements}

We are grateful to Privi life Science (Rwanda) Limited for providing the Silixol OSA liquid fertilizer and facilitating field works.

\section{References}

1. Ehrlich HL (1981) Geomicrobiology. Marcel Dekker Inc. p 393. New York

2. Sommer M, Kaczorek D, Kuzyakov Y, Breuer J (2006) Silicon pools and fluxes in soils and landscapes-a review. https://doi.org/10.1002/jpln.200521981

3. Meena VD, Dotaniya ML, Coumar V, Rajenduran S, Ajay, Kundu S, Rao AS (2014) A case for silicon fertilization to Improve Crop Yields in Tropical Soils. Proc. Natl. Acad. Sci., India, Sect. B Biol. Sci. https://doi.org/10.1007/s40011-013-0270-y

4. Zargar SM, Mahajan R, Bhat JA, Nazir M, Deshmukh R (2019) Role of silicon in plant stress tolerance: opportunities to achieve a sustainable cropping system. 3 Biotech. https://doi.org/10.1007/s13205-0191613-z 
5. Tubana BS, Heckman JR (2015) Silicon in soils and plants. In Rodri- gue FA, Datnoff LE (eds), Silicon and plant diseases. Cham: Springer, 7-51

6. Laane HM (2018) The effects of foliar sprays with different silicon compounds. Plants (Basel Switzerland). https://doi.org/10.3390/plants7020045

7. Neeru J, Shaliesh C, Vaishali T, Purav S, Manoherlal R (2019) Role of orthosilicic acid (OSA) based formulation in improving plant growth and development. Silicon. https://doi.org/10.1007/s12633-0159380-x

8. Epstein E (1999) Silicon. Ann. Rev. Plant Physiol. Plant Mol. Biol. https://doi.org/10.1146/annurev.arplant.50.1.641

9. Hodson MJ, White PJ, Mead A, Broadley MR (2005) Phylogenetic variation in the silicon composition of plants. Ann Bot. https://doi.org/10.1093/aob/mci255

10. Coskun D, Deshmukh R, Sonah H, Menzies JG, Reynolds OL, Ma JF, Kronzucker HJ, Belanger RR (2019) The controversies of silicon's role in plant biology. New Phytol. https://doi.org/10.1111/nph.15343

11. Ma JF, Takahashi E (2002) Soil, fertilizer, and plant silicon research in Japan. Elsevier, Amsterdam

12. Elsokkary IH (2018) Silicon as a beneficial element and as an essential plant nutrient: an outlook. Alexandria Science Exchange Journal. https://doi.org/10.21608/asejaiqjsae.2018.16920

13. Dobermann A, Fairhurst T (2000) Economics of fertilizer use. In: 'Rice: Nutrient disorders and nutrient management' (Potash and Phosphate Institute. Potash \& Phosphate Institute of Canada, and International Rice Research Institute, pp 50-119

14. Ahmad A, Afzal M, Ahmad AUH, Tahir M (2013) Effect of foliar application of silicon on yield and quality of rice (Oryza sativa L). Cercetari Agronomice in Moldova 46(3):21-28

15. Detmann KC, Araujo WL, Martins SC, Sanglard LMVP, Reis JV, Detmann E, Rodrigues FA, Nunes-Nesi A, Fernie AR, DaMatta FM (2012) Silicon nutrition increases grain yield, which, in turn, exerts a feed-forward stimulation of photosynthetic rates via enhanced mesophyll conductance and alters primary metabolism in rice. New Phytologist 196:752-762

16. Jan R, Aga FA, Bahar FA, Singh T, Lone R (2018) Effect of nitrogen and silicon on growth and yield attributes of transplanted rice (Oryza sativa L.) under Kashmir conditions. Journal of Pharmacognosy Phytochemistry 7(1):328-332

17. Song A, Li P, Fan F, Li Z, Liang Y (2014) The effect of silicon on photosynthesis and expression of its relevant genes in rice (Oryza sativa L.) under high-zinc stress. PLoS ONE 9(11):e113782

18. Jawahar S, Vijayakumar D, Bommera R, Neeru J, Jeevanandham (2015) Effect of silixol granules on growth and yield of rice. Int J Curr Res Aca Rev 3(12):168-174

19. Patil AA, Durgude AG, Pharande AL, Kadlag AD, Nimbalkar CA (2017) Effect of calcium silicate as a silicon source on growth and yield of rice plants. International Journal of Chemical Studies 5(6):545-549

20. Van Bockhaven J, Steppe K, Bauweraerts I, Kikuchi S, Asano T, Höfte M, De Vleesschauwer D (2015) Primary metabolism plays a central role in moulding silicon-inducible brown spot resistance in rice. Mol Plant Pathol. https://doi.org/10.1111/mpp.12236

21. Sun W, Zhang J, Fan Q, Xue G, Li Z, Liang Y (2010) Silicon-enhanced resistance to rice blast is attributed to silicon-mediated defence resistance and its role as physical barrier. Eur J Plant Pathol 128:39-49 
22. Fang CX, Wang QS, Yu Y, Huang LK, Wu XC, Lin WX (2011) Silicon and its uptaking gene Lsi1 in regulation of rice UV-B tolerance. Acta Agron Sin 37(06):1005-1011

23. Shi Y, Wang Y, Flowers TJ, Gong H (2013) Silicon decreases chloride transport in rice (Oryza sativa L.) in saline conditions. J Plant Physiol. https://doi.org/10.1016/j.jplph.2013.01.018

24. Mauad M, Crusciol CAC, Nascente AS, Filho HG, Lima GPP (2016) Effects of silicon and drought stress on biochemical characteristics of leaves of upland rice cultivars. Revista Ciência Agronômica. https://doi.org/10.5935/1806-6690.20160064

25. Dwivedi S, Kumar A, Mishra S, Sharma P, Sinam G, Bahadur L, Goyal V, Jain N, Tripathi RD (2020) Orthosilicic acid (OSA) reduced grain arsenic accumulation and enhanced yield by modulating the level of trace element, antioxidants, and thiols in rice. Environ Sci Pollut Res Int. https://doi.org/10.1007/s11356-020-08663-x

26. Li N, Feng A, Liu N, Jiang Z, Wei S (2020) Silicon application improved the yield and nutritional quality while reduced cadmium concentration in rice. Environ Sci Pollut Res Int. https://doi.org/10.1007/s11356020-08357-4

27. Pati S, Pal B, Badole S, Hazra GC, Mandal B (2016) Effect of silicon fertilization on growth, yield, and nutrient uptake of rice. Commun Soil Sci Plant Anal 47(3):284-290

28. Kowalska J, Tyburski J, Jakubowska M, Krzyminska J (2021) Effect of different forms of silicon on growth of spring wheat cultivated in organic farming system. Silicon. https://doi.org/10.1007/s12633020-00414-4

29. Zhang Y, Yu C, Lin J, Liu J, Liu B, Wang J, Huang A, Li H, Zhao T (2017) OsMPH1 regulates plant height and improves grain yield in rice. PLoS ONE. https://doi.org/10.1371/journal. pone.0180825

30. Yoshida S, Navasero SA, Ramirez EA (1969) Effects of silica and nitrogen supply on some leaf characters of the rice plant. Plant Soil. https://doi.org/10.1007/BF01373025

31. Hosseini SZ, Babaeian-Jelodar NA, Bagheri NA (2011) Effect of silica on morphological traits and resistance of rice to stripped stem borer, (Chilo suppressalis Walker). Plant Ecophysiology 3(2):95-100

32. Moghadam MRK, Heidarzadeh H (2014) Response of silicate fertilizer effects, rice husk and rice husk ash on rice paddy growth an seed yield (Shiroodi cultivar) in pot condition. International Journal of Farming Allied Sciences 3(4):449-452

33. Agostinho FB, Tubana BS, Martins MS, Datnoff LE (2017) Effect of different silicon sources on yield and silicon uptake of rice grown under varying phosphorus rates. Plants 6:35

34. Hattori T, Inanagaa S, Arakib H (2005) Application of silicon enhanced drought tolerance in sorghum bicolor. Physiol Plant 123:459-466

35. Dorairaj D, Ismail MR, Sinniah UR, Tan KB (2020) Silicon mediated improvement in agronomic traits, physiological parameters and fiber content in Oryza sativa. Acta Physiol Plant.

https://doi.org/10.1007/s11738-020-3024-5

36. Lavinsky AO, Detmann KC, Reis JV, Avila RT, Sanglard ML, Pereira LF, Sanglard LMVP, DaMatta FM (2016) Silicon improves rice grain yield and photosynthesis specifically when supplied during the reproductive growth stage. J Plant Physiol 206:125-132 
37. Tripathy S, Rath LK (2017) Silicon induced resistance expression in rice to Yellow stem borer. J Entomology Zoology Studies 5:12-15

38. Cuong TX, Ullah H, Datta A, Hanh TC (2017) Effects of silicon-based fertilizer on growth, yield and nutrient uptake of rice in tropical zone of Vietnam. Rice Sci. https://doi.org/10.1016/j.rsci.2017.06.002 39. NISR (National Institute Statistics of Rwanda) (2019) Seasonal Agricultural Survey annual report

\section{Figures}
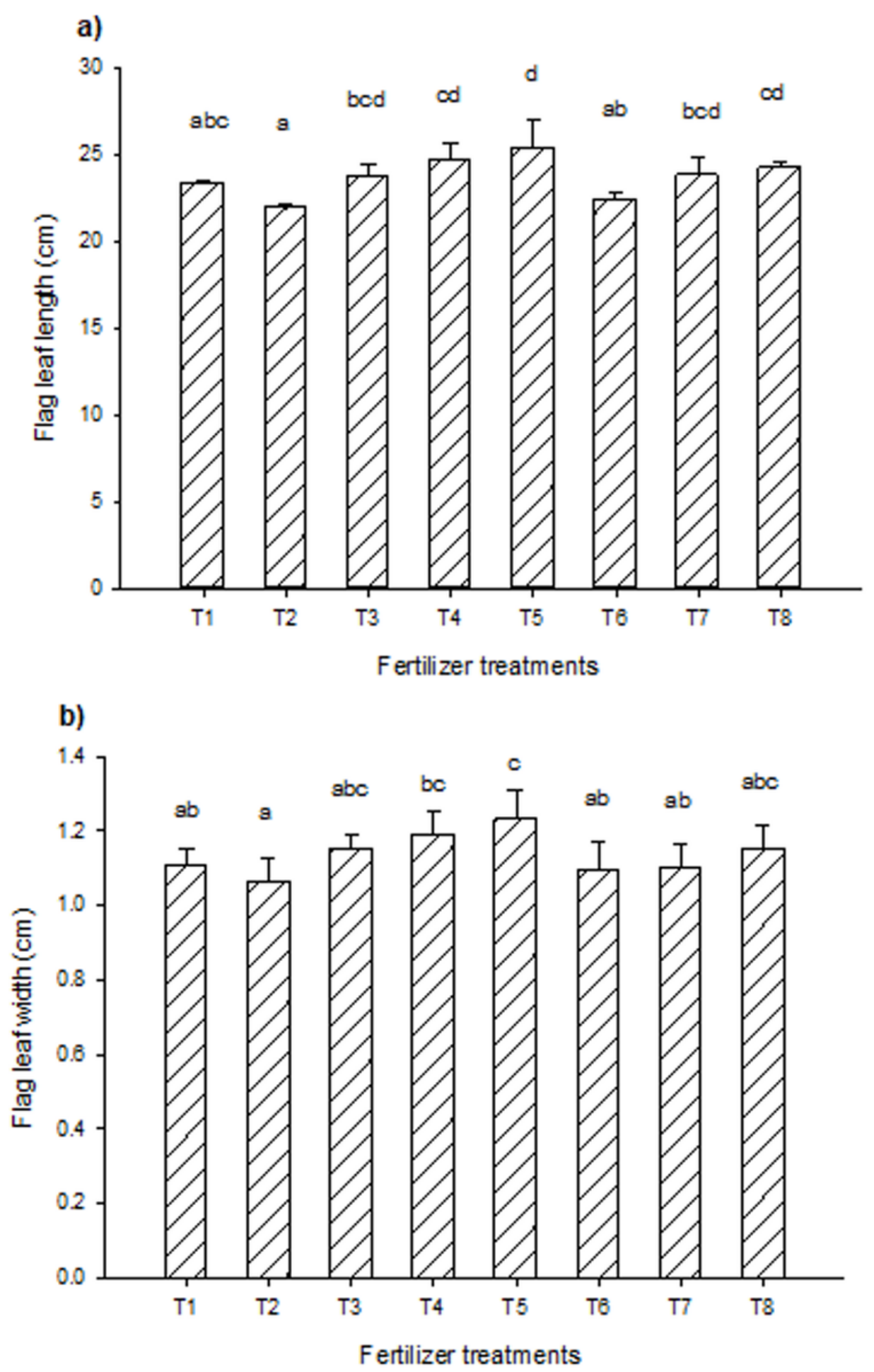


\section{Figure 1}

Effect of combined application of Si and NPK basal fertilizer on flag length (a) and flag width (b). 